\title{
Telomeres and Telomerase: Molecular Views and Perspectives
}

\author{
Kumar Arvind*, Tony Grace \\ Department of Genomic Science, Central University of Kerala, Kerala, India \\ Email: *karvind@cukerala.ac.in, *arvind90.psc@gmail.com
}

How to cite this paper: Arvind, $\mathrm{K}$. and Grace, T. (2018) Telomeres and Telomerase: Molecular Views and Perspectives. Food and Nutrition Sciences, 9, 91-111. https://doi.org/10.4236/aar.2018.75008

Received: December 30, 2016

Accepted: September 17, 2018

Published: September 20, 2018

Copyright $\odot 2018$ by authors and Scientific Research Publishing Inc. This work is licensed under the Creative Commons Attribution International License (CC BY 4.0).

http://creativecommons.org/licenses/by/4.0/

\begin{abstract}
Telomere, the nucleoprotein structure at the end of eukaryotic linear chromosomes is indispensable for maintaining the genome stability. Telomeric DNA loss is apparent with each cell division, which marks an endpoint to the indefinite replication of the cell by causing replicative senescence that may lead to the programmed cell death. The loss of telomere is normal in cell division and as such after 20 - 40 divisions, telomere becomes too short to facilitate the capping function. Telomere uncapping or chromosomal free end causes a potential threat to the genomic stability and thus leads to the accumulation of chromosomal abnormalities that have been known to play a role in aging and cancer. Telomerase, the ribonucleoprotein complex, and its accessory proteins are required to maintain the telomere sequence. Telomerase plays a key role in maintaining the length of telomere by adding G-rich repeat sequences. Its activity has been found to be quite high in the gametes, stem cells and most importantly tumor cells. Almost $85 \%$ of tumor cells compensate for telomere loss aided by telomerase-associated protein complex and shelter in complex or telosome. However, $5 \%-10 \%$ of the cells undergo telomerase-independent mechanism. This review presents the molecular view of the telomere and telomerase along with its associated complex structures. It also discusses its contrasting role in causing cellular senescence and promoting tumorigenesis.
\end{abstract}

\section{Keywords}

Telomere, Telomerase, Aging, Tumorigenesis, TMM, Shelterin

\section{Introduction}

Telomeres are chromatin structures that cap and protect the end of chromosomes. It is the end of eukaryote linear chromosomes, consisting of tandem ar- 
rays of G-rich repeats that protect the genome from degradation. A major part of the vertebrate telomere is packaged in closely spaced nucleosomes [1]. In mammals, telomeres comprise of thousands of tandem repeats of oligonucleotide sequence TTAGGG, associated with various specific proteins. Telomeric repeat sequences vary considerably between and within species [2]. In the case of humans, the length of telomeric repeat sequences has been reported up to $15 \mathrm{~kb}$ [3]. Telomere plays an indispensable role in protecting the chromosomal ends from fusion and degradation. During cell division, telomere compensates for DNA loss and consequently for telomere shortening [4].

Telomere plays a crucial role in aging. In human somatic cells, shortening of telomeres occurs with each cell division [5]. Since DNA polymerases are unable to completely replicate linear chromosomes, telomeres lose telomeric repeats progressively [2]. Progressive telomere shortening affects the chromosomal cap, which further leads to chromosomal instability, end-to-end fusion and ultimately cell death [1] [6]. The end-to-end fusion of chromosomes due to gradual telomere shortening may lead to the formation of dicentric chromosomes, which mark a potential threat to cellular viability. Chromosomal instability caused due to telomere loss is directly linked with apoptosis (Programmed cell death) as illustrated in Figure 1. Normally, the telomere is eroded after each cell division

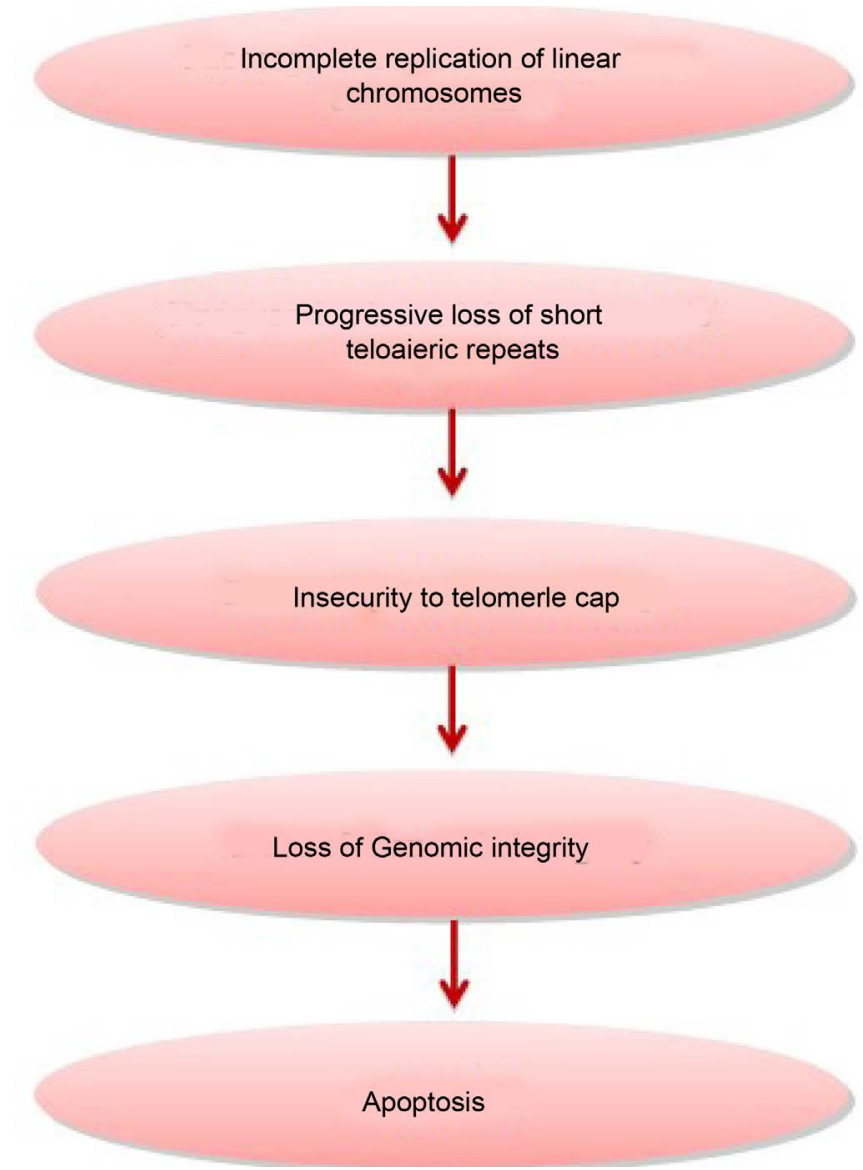

Figure 1. Flowchart representing the relationship between telomere loss and apoptosis. 
that results in the loss of about 50 - $200 \mathrm{bps}$. Gradually, due to the telomeric erosion, telomeric length becomes too short for the chromosome to be capped and provides a platform for nucleoprotein complex formation. Further, the chromosome is no longer able to bind shelterin or associated proteins, and thus telomere uncapping occurs. The uncapped telomere affects the genome integrity and paves the way for the cell towards programmed cell death [7]. According to Hayflick (1998), cell division stops after a certain number of cycles after which they enter into a stage of irreversible cell arrest or senescence [8]. Senescence of the cells is triggered through telomere signaling pathway, which involves p53 and RB protein factor [9]. Studies carried out on p53 and RB-deficient primary cell lines demonstrate the occurrence of a crisis in those cells, a period when such cells continue to grow, divide and cross the Hayflick's limit and end up with extreme shortening of telomere which further leads to genetic instability and finally massive apoptosis occurs [10]. Thus, erosion of telomere is one of the important mechanisms which limit the proliferative potential of individual cells [8] [11].

The gradual loss of telomeric repeats at the chromosomal ends affects cell function during aging. Typically, human chromosome ends have 2 - 10 kilobase pairs of detectable telomere repeats depending on the type of tissue, the age of the donor and the replicative history of the cells. Human chromosomal ends show marked variation in the average length of telomeres, for example, chromosome 17p has one of the shortest arrays of repeats [2]. The dramatic effect of the telomere loss is often conspicuous in cancer cells wherein gradual telomere loss is considered as DSBs (Double-stranded breaks). This situation results from the loss of tumor suppressor alleles and leads the cells towards a state of immortality [12]. Studies done on vascular endothelium cells showed an inverse relationship between telomeric length and age [13]. For human peripheral blood cells, telomere length appears to be a predictive marker of age-dependent mortality [14]. In order to compensate the telomere loss, telomerase and a complex network of telomere-associated proteins are needed. One remarkable feature of nucleoprotein structure located at the end of the chromosomes is to protect the chromosomal ends and prevent them from being considered as double-stranded breaks (DSBs).

\section{Telomere-Associated Structures}

Telomere protects the chromosomal ends by forming various higher order structures. The telomere-associated high order structures pose serious challenges for the maintenance of fidelity during DNA replication, repair and recombination which may cause potential threats to telomere stability [3]. Telomere capping at the end of the chromosome helps to avoid unwanted end-to-end fusion and thus maintains cellular viability. Telomere comprises of several kilobases of predominantly double-stranded repeat (for instance, TTAGGG in case of humans) and ends in a single strand overhang at the 3 ' end, which folds back onto duplex 
telomeric DNA and get annealed with complementary C-rich sequences at the proximal telomeric segment to form a lariat structure called "T-loop" structure [15].

T-loop is one of the highest order complex structures that telomeres attain to perform a remarkable function of protecting the chromosome by sequestering its free end Figure 2(a). Being sequestered, the chromosomal free ends are not recognized as DNA breaks and thus the occurrence of unwanted DNA damage responses get restricted [7]. A multisubunit protein complex called shelterin (also called as telosome) promotes formation of T-loop. Shelterin is a six protein subunit complex and includes TRF1 and TRF2 (telomeric repeat binding factors), POT1 (protection of telomeres), RAP1 (transcription repressor/activator protein 1), TIN2 (TRF1 interacting protein 2) and TPP1 (POT1 and TIN2-organizing protein) [16]. TRF1 and TRF2 are telomere-associated dimers reported to restrict telomere elongation by telomerase and thus termed as negative regulators of telomeric length [16] [17]. Shelterin binds specifically to telomeric DNA and provides a protective capping to the chromosomal end. Telomeric repeat sequences prepare a ground for the specificity of Shelterin towards telomeric DNA. TRF1, TRF2 and POT1 are the first three components of Shelterin to identify TTAGGG repeat sequences and bind specifically to it. TRF1 and TRF2 bind to the double-stranded telomeric DNA whereas POT1 binds to single stranded 3' overhang as well as the D-loop [16]. D-loop is formed as a result of G-rich 3'overhang strand invasion and followed by its hybridization with proximally lying c-rich complementary sequences [17]. Studies done so far reveal quite contrasting features of the Shelterin complex, TRF1 and TRF2. Of the components of shelterin complex, TRF1 and TRF2 share some common structural features (similar homology domain) called TRFH domain and DNA binding domain i.e. myb [15] [19]. In knockout studies, it has been shown that disruption of TRF2 and Ku70 leads to DNA damage signal, telomere homology recombination process and sister-chromatid exchange [20] [21]. The role of TRF2 in association with RAP1 is critical in inhibiting the process of homologous recombination. Likewise, disruption of POT1 has also been shown to activate ataxia, telangiectasia and $\operatorname{Rad} 3$ protein factors (ATR), which may cause DNA damage and eventually lead to telomeric fusions [22] [23]. Moreover, p53 plays a dynamic role in protecting T-loop formation. Stansel et al. (2002) in an in vitro study demonstrated the affinity of p53 towards the 3 'overhang region which was not sequence specific [24]. Most interestingly, it was also observed that the efficiency of T-loop formation doubled when catalyzed by TRF2 in the presence of p53, which clearly depicts the unique role of p53 in T-loop formation [24]. However, the detailed molecular mechanism associated with T-loop, its dynamics and the way it persists throughout the cell cycle is not yet clear.

The detailed formation of Shelterin protein complex is illustrated in Figure 2(b). Apart from shelterin complex, mammalian telomeres have also been 


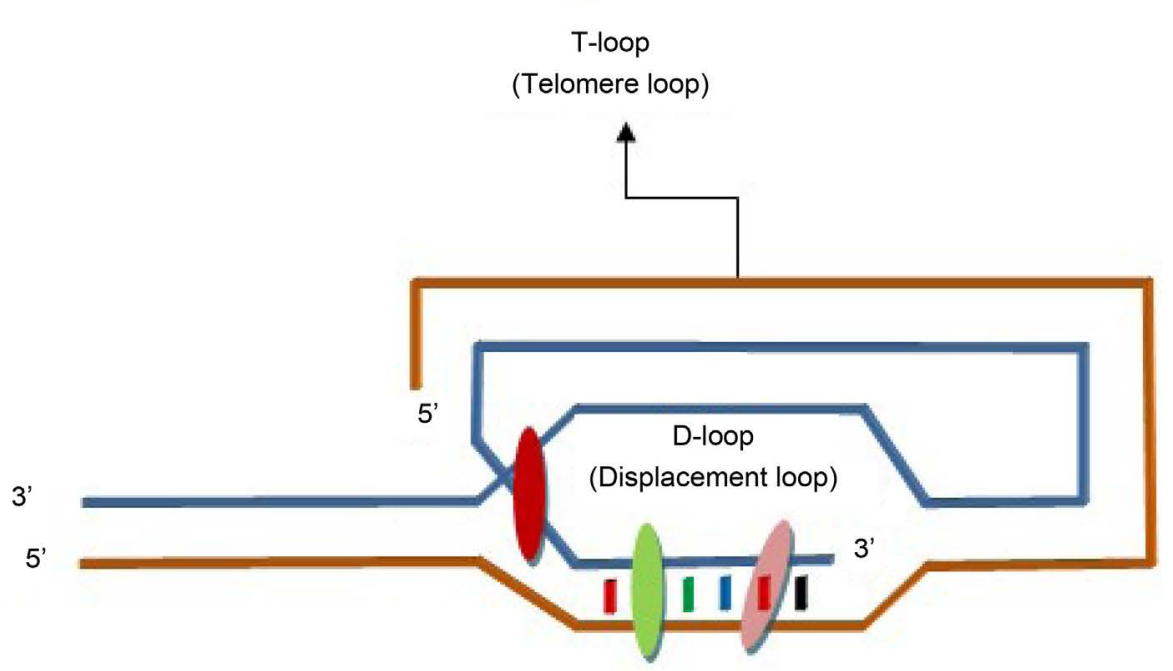

(a)
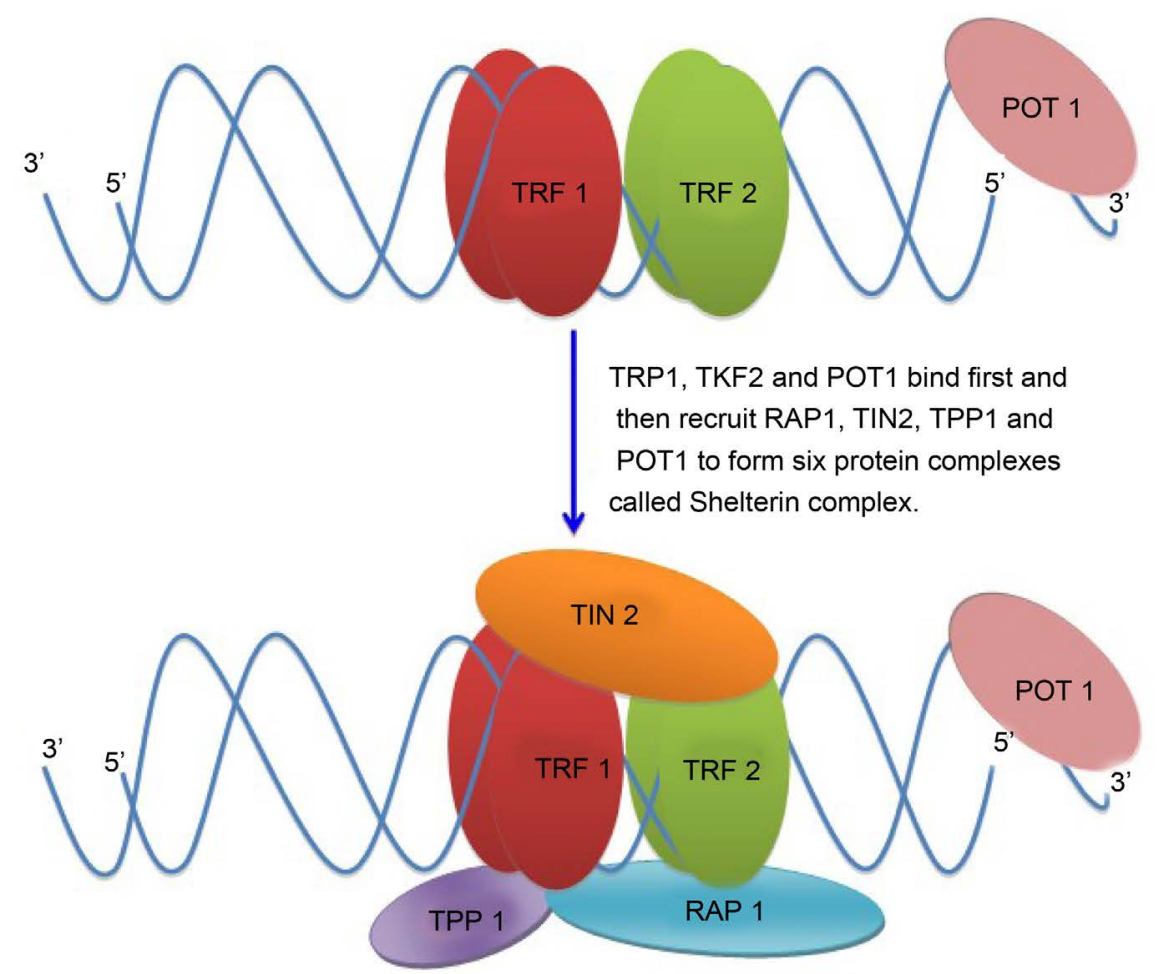

(b)

Figure 2. Nucleoprotein structure of telomere in mammals. (a) Schematic representation of T-loop structure and associated protein factors. The lariat structure formation is caused due to the looping back of telomeric DNA. As a result of which 3' G strand extension invades the duplex telomeric repeats and the formation of D-loop results as well; (b) The double stranded telomeric DNA is surrounded by Shelterin, a multiprotein complex which includes (TRF1, TRF2, POT1, TIN2, RAP1 and TPP2). TRF1, TRF2 and POT1 are recruited first wherein TRF1 and TRF2 bind to the double stranded region of the telomere and POT1 binds to the single strand overhang. POT1 and TPP combine to form heterodimer complex and bind to the single stranded telomeric DNA overhang. Subsequently, other three additional proteins (RAP1, TIN2 and Tpp1) are recruited to form six subunit complex formation, Shelterin. 
associated with other accessory factors which include tankyrase 1 and 2, Poly (ADP-ribose) polymerase1 (PARP1), Ataxia-telangiectasia mutated (ATM), and Rad3-related (ATR), as well as general DNA replication and repair or recombination factors [25]. These factors restrict telomeric DNA from being recognized as damaged DNA and promote proper telomeric replication. Most importantly, shelterin fosters the formation of T-loop and thus displays fusion-inhibitory activity by inhibiting the fusion of chromosomal ends.

In human, single-stranded telomere with 3' G-overhang causes the formation of other higher order structure G-quadruplexes [26]. The G-quadruplexes are highly stable secondary coplanar structures and forms anywhere along the long G-rich strand. The coplanar structure of G-quadruplexes involves the presence of four guanine bases interconnected with the pairs of hoogsteen hydrogen bonds and stacked with each other to form G-tetrad structure [18]. The presence of electronegative O-6 guanine carbonyl group towards the center of each tetrad provides the site for the interaction of small ions like $\mathrm{Na}^{+}$ions or $\mathrm{K}^{+}$ions which invokes high stability to the G-quadruplex structures [27]. In vitro study on Oxytrich nova's telomerase suggests that the stability of the structure is inferred by the binding of $\mathrm{K}^{+}$ion [28]. $\mathrm{K}^{+}$ion coordinates between the adjacent strands and "G-bases" in G-quadruplexes, serves as both donor and acceptor for hydrogen bond formation and thus G-quadruplexes includes intra- or intermolecular interaction of G-rich single-stranded telomeric ends. In humans, the functional roles of G-quadruplexes include telomere protection, suppression of recombination, gene expression, and inhibition of telomerase-dependent telomere extension and telomere maintenance [29] [30]. Formation of the G-quadruplex structure causes the unavailability of free 3 ' telomeric end region to bind with the RNA template of telomerase and thus hinders the catalytic activity of the enzyme complex [28]. The G-quadruplex formation is also one of the several potential obstacles telomeres pose to DNA during replication. Therefore, unfolding of G-quadruplex is required for the attachment of telomerase and executing its catalytic activity [31] [32]. Thus, it could be said that stabilization of G-quadruplex inhibits the action of telomerase. The factors like small molecules, which favor the stability, prove to be a selective target of immortalized cells wherein active telomerase is found to be quite high. The concerned approach has led to widespread development of anti-cancer therapeutic agents viz., BRACO-19, RHPS4, telomestatin and tetra substituted naphthalenediamide which are proved to be effective candidates against cancer cells by altering the telomere maintenance [33] [34] [35] [36]. A schematic model representing the formation of G-quadruplex is shown in Figure 3.

\section{Telomerase-A Molecular Insight}

Human telomerase is a ribonucleoprotein holoenzyme complex which functions to extend telomeric DNA and acts to compensate telomere loss [6]. Telomerase comprises of a catalytic protein subunit which belongs to the family of reverse 


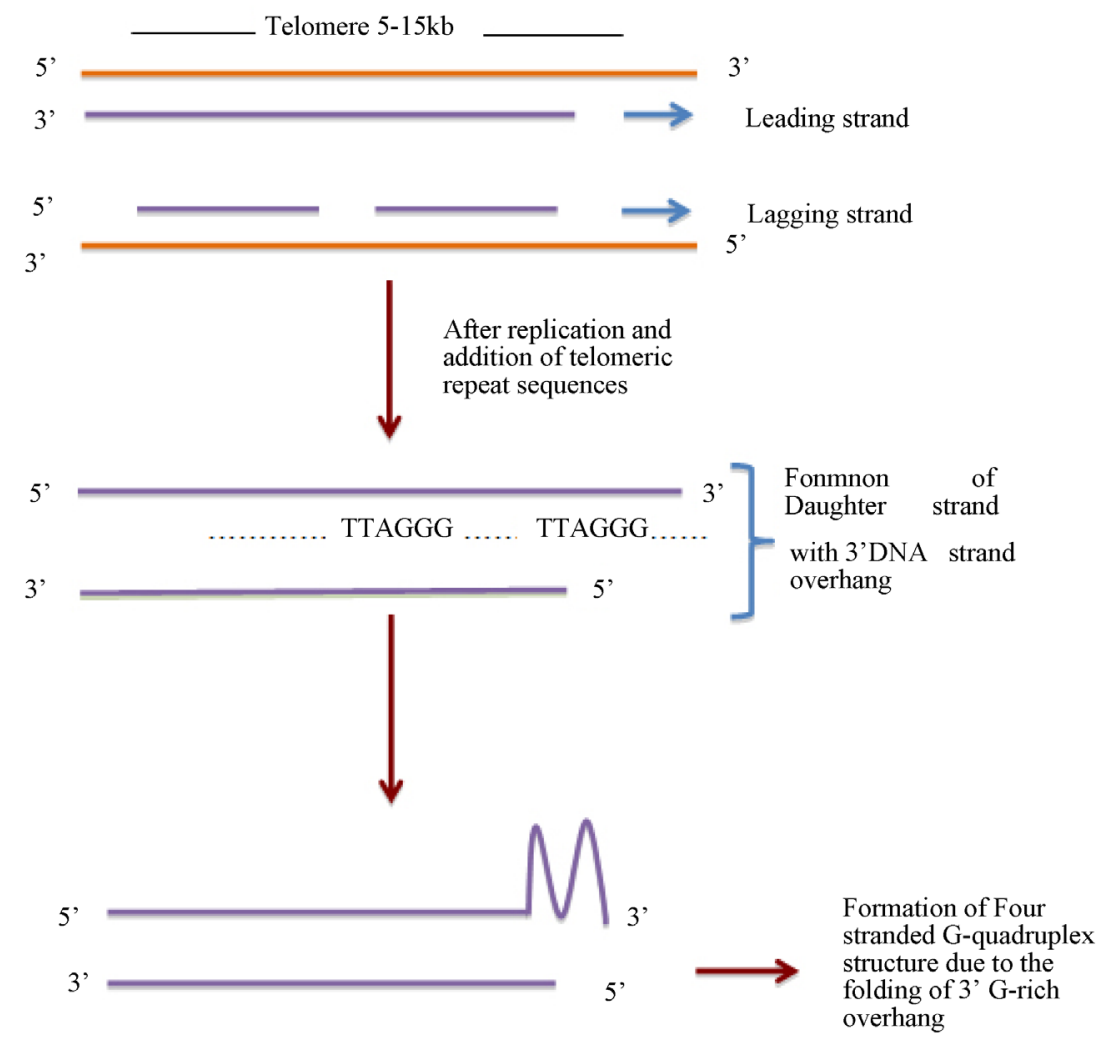

Figure 3. Formation of G-quadruplex: As a result of replication and addition of telomeric repeat sequences by telomerase, one of the daughter strand (lagging strand) get shortened and thus, results in the formation of 3' single-stranded G-rich overhang.

transcriptase (hTERT) encoded by hTERT gene in human. It also includes hTR region, encoded by the TERC gene which works as a template during telomere maintenance process [4] [10] [37]. The associated proteins dyskerin, NOP10, NHP2, GAR1, TCAB1 and several other species-specific cofactors have been found to be involved in the holoenzyme complex [38] [39]. The hTERT gene (encodes TERT) which utilizes hTR, acts as the RNA template to reverse transcribe the telomeric DNA repeats. Out of the four functional regions of hTR viz., CR4-CR5 domain, Pseudoknot region, Box H/ACA and CR7 domain, CR4-CR5 domain and Pseudoknot region bind with the TERT protein and are required for enzymatic activity of the complex [14]. Telomerase-associated proteins viz., dyskerin, NOP10 and NHP2 are involved in providing stability and promoting the association of hTR [16]. Other accessory proteins as depicted in Figure 4(b) are required for proper assembly and function of the telomerase complex which include dyskerin, NOP10, NHP2 and GAR1 [40]. Gomez et al. (2012) demonstrated a current model for the formation of the complete ribonucleoprotein complex, which is initiated, with a scaffold formation [16]. The formation of scaffold involves three critical protein factors viz., dyskerin, pontin and reptin which provide a platform for the recruitment of hTR and other accessory protein factors Figure 4(a). Recruitment of hTR by the associated protein factors 


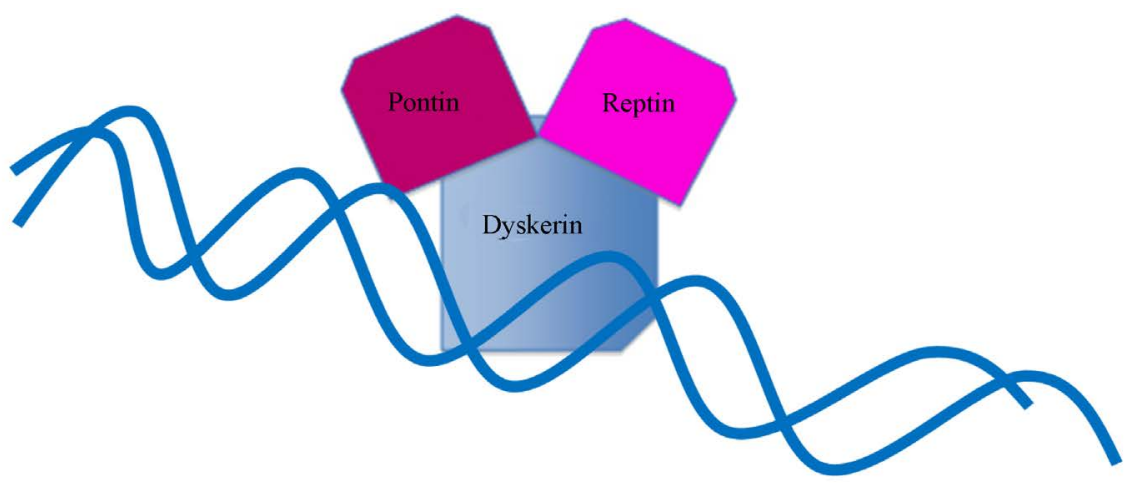

(a)

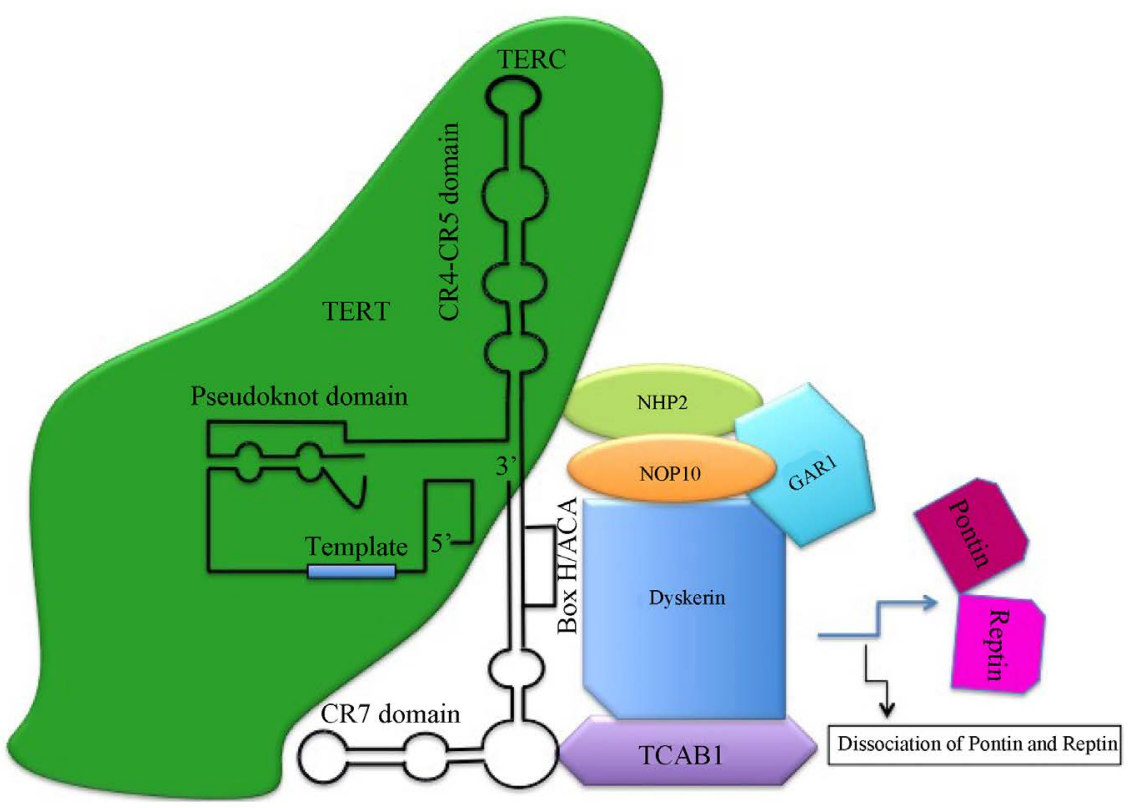

(b)

Figure 4. Schematic representation of Telomerase complex formation. (a) Dyskerin, pontin, and reptin combine to form a scaffold for the recruitment of the accessory proteins; (b) The simplified molecular structure of telomerase depicting its associated crucial components. Functional regions of hTERC RNA are also shown. Pontin and reptin dissociate after complex formation.

facilitates the formation and stability of ribonucleoprotein complex which is followed by the dissociation of the pontin and reptin as shown in Figure 4(b).

The telomere is thought to be an internal clock which terminates a cell's life [41]. Telomerase compensates the loss of telomere end sequences during cell division by adding specific DNA repeats at the chromosomal 3' ends [42]. It synthesizes and maintains telomeric units to counter the end replication problem by adding repeated oligomer sequence to the 3 ' terminus of chromosomal DNA [43]. The process of telomere elongation involves various stages as represented in Figure 5. The template sequence of 11 complementary nucleotides located inside the RNA domain of the telomerase ribonucleoprotein complex gets hybridized with the complementary two telomeric repeats found at the 3 ' extreme of 


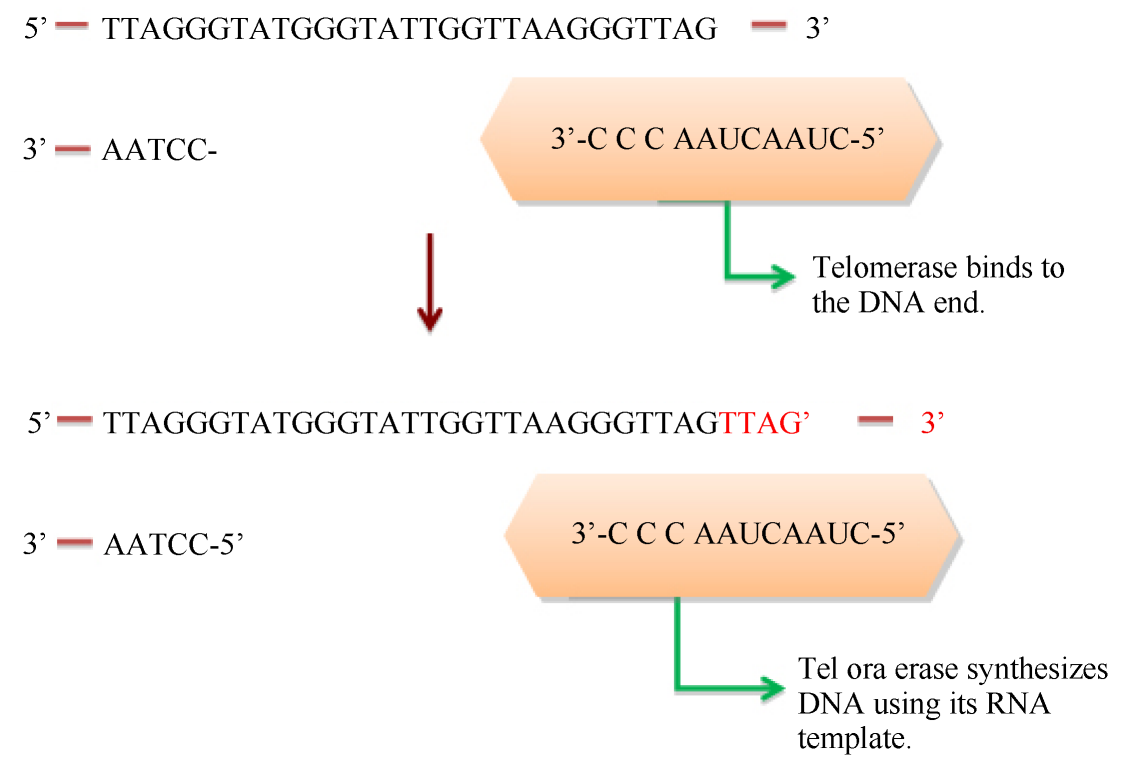

Figure 5. Schematic representation of the telomere maintenance by telomerase. $11 \mathrm{com}$ plementary nucleotides at the RNA domain of the telomerase act as a template for telomere elongation. It hybridizes with the complementary two telomeric repeats found at the 3' extreme of telomeric DNA. The gap so forms at the 3'end is filled by hTERT component of the telomerase.

telomeric DNA which are followed by the synthesis of nucleotide sequences by hTERT. The gaps which are found at the extreme of the template are filled and the synthesis of hexanucleotides repeat gets completed. The completion of hexanucleotide formation is followed by synthesized strand translocation in 5' direction, which causes the formation of a new gap. The new gap is filled with the same steps and the cycle continues to get repeated to attain a specific length [38].

Normally, telomerase activity is observed in those cell types that replicate successfully and most importantly those which exhibits regenerative activity, such as sperm cells [44], stem cells [45] and activated lymphocytes [46]. During S-phase in most somatic cells, some telomerase activity is transiently expressed [47] and is critical for cell cycle transit and for preventing or delaying cellular senescence. Telomerase supports the replicative potential of proliferating cells.

Telomeric length is frequently being used a marker of somatic cells replicative history. Several studies done so far suggest that telomeric length can be used as surrogate marker for various other tissues based on the investigated measurement of telomere length in white blood cells [48]. In a recent study, it has been shown that two core components of telomerase viz., hTERT and hTERC undergo a gradual reduction in expression with increased age [49]. As far as the consistency of telomeric length is concerned, the studies done in leucocytes found it to be consistent with age, gender and race but the consistency of telomeric length in leucocytes with other phenotypes, such as smoking, socioeconomic status and education, alcohol consumption, body mass index, lipid levels, marker of glucose metabolism, physical activity, diets, and blood pressure has not 
been found [50].

\section{TERC and TERT Genes}

hTERT gene is located on chromosome 5p15.33 and encodes a protein called hTERT which consists of 1,132 amino acids (Human Reverse Transcriptase) and forms the catalytic subunit of the telomerase. hTERC gene that is located on chromosome 3q21-q28, encodes telomerase RNA and consists of 451 nucleotides [51]. It serves as an RNA template that associates with the Reverse transcriptase family and forms telomerase ribonu cleoprotein complex [52]. Human hTERT has been found to express only in telomerase-positive cells [44] [53]. In human, hTERC has been shown to be ubiquitously expressed in germ cell lines and stem cells [37]. Moreover, it has been reported that in most human tumors, chromosomal gains and gene amplification involving chromosome arm 3q (TERT and TERC telomerase subunit genes) has been found to be more frequent [54] [55]. Studies suggest that mutations in hTERC gene give rise to an array of human diseases, for instance, autosomal dominant dyskeratosis congenital disease in humans [56]. Chromosomal instability and accelerated cellular senescence have been investigated in patients affected by dyskeratosis congenital and idiopathic pulmonary fibrosis, especially in tissues with a high proliferative activity [57].

\section{5. hTERT and hTERC-Components of Telomerase}

Telomerase activity requires catalytic subunit hTERT and the RNA subunit hTERC for reverse transcription [58] [59]. Studies done so far to understand the structure and function of TERT reveal that homologs of TERT share a common domain structure. The catalytic subunit of the TERT ( $127 \mathrm{kda})$, is found in the C-terminal region of the protein [16]. TERT, like other polymerases, contains a triad of absolutely conserved aspartic acid (Asp) residues and the conserved aspartic acid residue is required for metal binding and enzyme chemistry [59].

The human telomerase reverse transcriptase is a catalytically active component of the telomerase complex and plays a crucial role in catalyzing the telomerase elongation process, genome stability and enhanced DNA-repair [60] [61]. hTERT in association with an RNA template molecule (hTERC) and a number of telomerase-associated proteins form the active enzyme complex and execute its canonical function of telomerase protection [37] [62] [63] [64]. Studies suggest that there is a steady decrease in the expression level of hTERC and hTERT gene during the human gestational age of 6 - 11 weeks [65].

The activity of the telomerase depends particularly on hTERT, the catalytic component of telomerase and is considered to be the rate-limiting component of telomerase activity [66] [67] [68]. Studies done on mice and cultured cells, in the absence of telomerase enzymatic activity, revealed novel functions of telomerase and its functional subunit TERT apart from its canonical role in telomere maintenance. Telomerase in association with TERT has been found to execute some telomere-independent activity. Telomere-independent activity of telomerase in- 
cludes enhancement of cellular proliferation, providing resistance to cellular senescence [69]. It has also a potential role in DNA repair mechanisms [70], signal amplification through wnt pathway [71], RNA-dependent RNA polymerase function [72]. Moreover, TERT also plays a crucial role in mitochondrial ROS (Reactive Oxygen Species) production and takes an active part in mitochondrial metabolism as well [73].

Experimental studies suggest an active role of TERT in cancer cells. Since telomere maintenance is one of the key events in cancer, it causes activation of the hTERT gene by chromatin remodeling [74] [75]. Reste et al. (2014) implicates in their study that in order to initiate the upregulation of telomerase gene, the combined contribution of several conditions viz., a specific mixture of regulating cytokines and a certain confirmation of telomeric ends is required simultaneously [41]. Upregulation of telomerase activity is partly independent of hTERT mRNA expression as in some studies the later was demonstrated to remain unaffected [76] [77]. It has been proposed that excess of TERC gene dose is detrimental and can play a role in promoting cancer [54] [78] [79]. TERT activity has been extensively studied during the last decade but many questions still remain unanswered. Activation of the hTERT gene regulation is still unclear.

\section{Telomerase: Path towards Tumorigenesis}

After each division of somatic cells, telomere shortening occurs due to the inability of DNA polymerase to completely replicate chromosomal ends. Cells are thus restricted to undergo a finite number of cell divisions, marking a checkpoint for creating genome instability and malignant formation [25]. As explained earlier telomere prevents the misrecognition of chromosomal ends as DSB (double-strand breaks). Loss of this function is the basis of malignant cells where progressive telomere shortening generates DNA ends which could not be distinguished from strand breaks. As a consequence of which the loss of tumor suppressor alleles and the formation of fusion genes having altered function occur due to chromosomal instability and aneuploidy, ultimately lead to the molecular pathway towards tumorigenesis [3]. It has been found that cells become immortalized and start to undergo uncontrolled proliferation by acquiring a telomere maintenance mechanism (TMM), which helps such cells to stave off induction of senescence. Mostly, active role of telomerase in TMM has been observed in almost all human cancer. But, about $5 \%-10 \%$ of immortalized cells escape crisis through a process termed ALT (Alternative Lengthening of the Telomeres) [80] [81]. Studies done on telomerase-RNA deficient mice, telomerase-lacking yeast, and in mosquito (Anopheles gambiae) and fruitfly (Drosophila melanogaster) support the occurrence of ALT in such cells [82] [83] [84] [85]. Such immortalized cells maintain the length of telomere without the aid of telomerase and are found to be more common in tumors derived from mesenchymal cells [81]. ALT cells have been characterized with long and heterogeneous telomeres $(2-20 \mathrm{~kb})$, long and extrachromosomal telomeric repeats and the 
presence of ALT-associated promyolytic leukemia bodies (ABPs) [86].

Telomerase instability paves a molecular path towards cancer. In cellular biology, the role of telomerase is of growing complexity. Telomerase activity is known to be absent in most human somatic cells, as an effect of which telomere shortening is known to occur and thus poses a barrier to tumor growth and marks a molecular path towards aging. But in the majority of malignant cells wherein telomere shortening is staved off as a result of the telomere dysfunction, telomerase activity has found to be high. These contrasting approaches are represented schematically in Figure 6.

Among most human tumors, chromosomal gain and gene amplification involving chromosome arm $3 q$ is found to be more frequent and signifies the involvement of telomerase-associated subunits in malignancies formation [54] [55]. Studies suggest that hTERT is frequently expressed during the early tumor development and allows the clone to bypass mitotic breakdown and replicative senescence and thus causes the malignant to get immortalized [87] [88]. hTERT activity is a key step in hepatocellular carcinoma (HCC) cell proliferation, apoptosis, and immortality [89]. Most interestingly, recent studies on hepatocellular carcinoma (HCC) and precancerous tissues, demonstrate a negative correlation between tumor suppressor gene phosphatase and tensin homolog (PTEN) expression levels and telomerase activity [66]. PTEN, a tumor suppressor gene with dual-specific phosphatase activity, is a critical signaling molecule in the upregulation of cell proliferation and apoptosis. The study also suggested that PTEN and hTERT have opposing roles in HCC development. It has been observed that expression level of hTERT protein was extremely higher in hepatocellular carcinoma (HCC) as compared with that of the corresponding precancerous tissues which signify hTERT to act as a tumor marker [66].

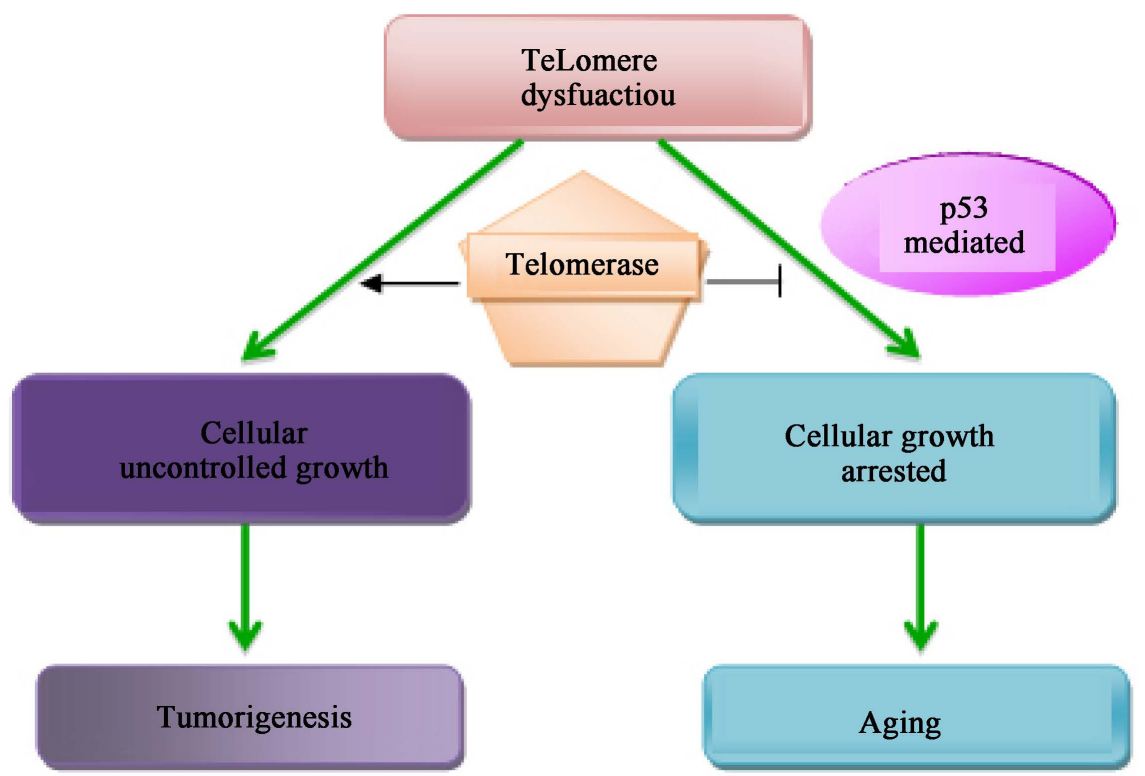

Figure 6. Schematic representation of telomeric effect in two contrasting aspects associated with telomere dysfunction. 
Being the catalytic subunit of the enzyme telomerase, its potential role in promoting tumorigenesis has been reported. In several of human cancer including glioma, melanoma, and bladder, the somatic mutations in the promoter region of TERT have been reported specifically at $-124,-146$ bp which lie in the upstream region of the transcription start site [90]. In many of the recent mutational studies, it has been reported that mutation in the promoter region of the TERT gene is associated with a number of malignancies. Mutation in the promoter increases the transcriptional efficiency of the TERT gene. Huang et al. (2015) reported de novo generation of motifs for ETS (E-twenty-six) transcription factors binding as a result of mutation in the TERT promoter region to promote transcriptional efficiency [91]. Mutational studies done so far, have reported the following mutations in the promoter region of hTERT: C228T, C250T, A161C, C158A, G149T, C242T + C243T, G245A T198G, C193T, C190T $+\mathrm{C} 184 \mathrm{~T}$ and $\mathrm{C} 250 \mathrm{~T}+\mathrm{C} 242 \mathrm{~T}+\mathrm{C} 243 \mathrm{~T}$. Out of 11 reported mutations, C228T and C250T have been found to be the most common mutations [91]. Recently, Huang et al. (2015) reported 4 novel mutations (T198G, C193T, C190T + C184T and $\mathrm{C} 250 \mathrm{~T}+\mathrm{C} 242 \mathrm{~T}+\mathrm{C} 243 \mathrm{~T}$ and on the basis of TRAP assay claims a positive correlation between TERT promoter mutation and telomerase activation [91]. Moreover, Killela et al. (2013) suggest that tumor could be categorized into two categories on the basis of TERT promoter mutational frequency (TPMF) i.e. low TPMF $(<15 \%)$ and high TPMF $(\geq 15 \%)$ tumors [92]. Mutations associated with the promoter region of TERT are described in Table 1.

It has also been proposed through the studies done so far that carcinogenesis may be promoted by increasing the TERC gene dose, possibly through a different mechanism that is independent of telomerase. TERC gene copy number proves to be a prospective explanation for the increased risk of malignancies,

Table 1. Representing mutation associated with promoter region of TERT in various cancers.

\begin{tabular}{|c|c|c|c|c|}
\hline S. No. & Tumor type & Mutational region & Frequency & References \\
\hline 1. & Human melanoma & $\begin{array}{c}\text { Promoter region of } \\
\text { hTERT }\end{array}$ & $70 \%$ & [93] \\
\hline 2. & Primary glioblastoma & $\begin{array}{c}\text { Promoter region of } \\
\text { TERT }\end{array}$ & $80.3 \%$ & [94] \\
\hline 3. & Metastatic melanoma & $\begin{array}{c}\text { Promoter region of } \\
\text { TERT }\end{array}$ & $85 \%$ & [95] \\
\hline 4. & Hepatocellular carcinoma & $\begin{array}{c}\text { Promoter region of } \\
\text { TERT }\end{array}$ & $29.2 \%$ & [96] \\
\hline 5. & $\begin{array}{c}\text { Urothelial cell carcinoma of } \\
\text { bladder }\end{array}$ & $\begin{array}{c}\text { Promoter region of } \\
\text { TERT }\end{array}$ & $65.4 \%$ & [97] \\
\hline 6. & Cutaneous Melanoma & $\begin{array}{c}\text { Promoter region of } \\
\text { TERT }\end{array}$ & $43 \%$ & [98] \\
\hline 7. & Papillary thyroid cancer & $\begin{array}{c}\text { Promoter region of } \\
\text { TERT }\end{array}$ & $11.7 \%$ & [99] \\
\hline 8. & Lung cancer & $\begin{array}{c}\text { Promoter region of } \\
\text { TERT }\end{array}$ & $2.57 \%$ & [100] \\
\hline 9. & $\begin{array}{l}\text { Clear cell retinal cell } \\
\text { carcinoma (ccRCC) }\end{array}$ & $\begin{array}{c}\text { Promoter region of } \\
\text { TERT }\end{array}$ & $6.4 \%$ & [101] \\
\hline
\end{tabular}


which are found in individuals with aneuploidy [102]. A study implicates that in amniocytes, retrieved from fetuses with various aneuploidies, TERC copy number has been found to be a parameter of genetic instability [102]. A study on telomerase-null mice showed a rapid decrease in the length of telomere during the early cleavage developmental process which proved to be evidence that recombination-based mechanism rather than telomerase is responsible for the lengthening of telomere during the early cleavage cycles following fertilization [103]. Telomerase performs a regulatory role in cell immortalization and thus proves to be an attractive anti-cancer target. Therefore, telomere maintenance inhibitors get a considerable interest as a broad-spectrum cancer therapy agent [104]. However, TMM, as well as ALT mechanism, continues to unravel the crossroad pathways towards solving the molecular queries regarding cancer.

\section{Conclusion}

Telomere capping plays a crucial role in the maintenance of linear chromosomes, providing protection and stabilization. Telomerase activity has been found to be high in almost all malignant cells which result in telomere dysfunction and thus paves a molecular pathway towards the discovery of telomeres and the associated indispensable telomere maintenance factors. Telomerase related study has still miles to go as molecular dynamicity and assisting protein factors are yet to be explored. T-loop and G-quadruplexes structures which provide stability to the telomeric end may be hotspots for anticancer therapeutics. The investigation of the extra-telomeric functions of the catalytic subunit of telomerase, TERT, has offered new insights into the role of telomerase in cell biology. Moreover, apart from its role in controlling the cell division through apoptosis, anti-apoptotic functions of TERT need to be methodically investigated. Most importantly, the contribution of ALT cells in tumorigenesis remains to be a fascinating and significant area for further research.

\section{Conflicts of Interest}

The authors declare no conflicts of interest regarding the publication of this paper.

\section{References}

[1] Blackburn, E.H. (2001) Switching and Signaling at the Telomere. Cell, 106, 661-673. https://doi.org/10.1016/S0092-8674(01)00492-5

[2] Lansdorp, P.M. (2005) Major Cutbacks at Chromosome Ends. Trends in Biochemical Sciences, 30, 388-395.

[3] Liew, L.P. and Norbury, C.J. (2009) Telomere Maintenance: All's Well That Ends Well. Archives of Toxicology, 83, 407-416.

https://doi.org/10.1007/s00204-009-0423-1

[4] Harley, C.B., Futcher, A.B. and Greider, C.W. (1990) Telomeres Shorten during Ageing of Human Fibroblasts. Nature, 345, 458-460. https://doi.org/10.1038/345458a0

[5] Allison, L.A. (2007) Fundamental Molecular Biology. Blackwell Publishing, Malden, 
MA, 138-149.

[6] McEachern, M.J., Krauskopf, A. and Blackburn, E.H. (2000) Telomeres and Their Control. Annual Review of Genetics, 34, 331-358.

https://doi.org/10.1146/annurev.genet.34.1.331

[7] Conomos, D., Pickett, H.A. and Reddel, R.R. (2013) Alternative Lengthening of Telomeres: Remodeling the Telomere Architecture. Frontiers in Oncology, 3, 27. https://doi.org/10.3389/fonc.2013.00027

[8] Hayflick, L. (1998) How and Why We Age. Experimental Gerontology, 33, 639-653. https://doi.org/10.1016/S0531-5565(98)00023-0

[9] Shay, J.W., Pereira-Smith, O.M. and Wright, W.E. (1991) A Role for Both RB and p53 in the Regulation of Human Cellular Senescence. Experimental Cell Research, 196, 33-39. https://doi.org/10.1016/0014-4827(91)90453-2

[10] Counter, C.M., Avilion, A.A., LeFeuvre, C.E., Stewart, N.G., Greider, C.W., Harley, C.B. and Bacchetti, S. (1992) Telomere Shortening Associated with Chromosome Instability Is Arrested in Immortal Cells Which Express Telomerase Activity. The EMBO Journal, 11, 1921-1729.

[11] Hayflick, L. and Moorhead, P.S. (1961) The Serial Cultivation of Human Diploid Cell Strains. Experimental Cell Research, 25, 585-621. https://doi.org/10.1016/0014-4827(61)90192-6

[12] Maser, R.S. and DePinho, R.A. (2002) Connecting Chromosomes, Crisis, and Cancer. Science, 297, 565-569. https://doi.org/10.1126/science.297.5581.565

[13] Chang, E. and Harley, C.B. (1995) Telomere Length and Replicative Aging in Human Vascular Tissues. Proceedings of the National Academy of Sciences of the United States of America, 92, 11190-11194.

[14] Cawthon, R.M., Smith, K.R., O’Brien, E., Sivatchenko, A. and Kerber, R.A. (2003) Association between Telomere Length in Blood and Mortality in People Aged 60 Years or Older. The Lancet, 361, 393-395. https://doi.org/10.1016/S0140-6736(03)12384-7

[15] Palm, W. and de Lange, T. (2008) How Shelterin Protects Mammalian Telomeres. Annual Review of Genetics, 42, 301-334. https://doi.org/10.1146/annurev.genet.41.110306.130350

[16] Gomez, D.E., Armando, R.G., Farina, H.G., Menna, P.L., Cerrudo, C.S., Ghiringhelli, P.D. and Alonso, D.F. (2012) Telomere Structure and Telomerase in Health and Disease (Review). International Journal of Oncology, 41, 1561-1569. https://doi.org/10.3892/ijo.2012.1611

[17] Pfeiffer, V. and Lingner, J. (2013) Replication of Telomeres and the Regulation of Telomerase. Cold Spring Harbor Perspectives in Biology, 5, a010405. https://doi.org/10.1101/cshperspect.a010405

[18] Nandakumar, J. and Cech, T.R. (2013) Finding the End: Recruitment of Telomerase to Telomeres. Nature Reviews Molecular Cell Biology, 14, 69-82. https://doi.org/10.1038/nrm3505

[19] König, P., Fairall, L. and Rhodes, D. (1998) Sequence-Specific DNA Recognition by the Myb-Like Domain of the Human Telomere Binding Protein TRF1: A Model for the Protein-DNA Complex. Nucleic Acids Research, 26, 1731-1740. https://doi.org/10.1093/nar/26.7.1731

[20] Celli, G.B. and de Lange, T. (2005) DNA Processing Is Not Required for ATM-Mediated Telomere Damage Response after TRF2 Deletion. Nature Cell Biology, 7, 712-718. https://doi.org/10.1038/ncb1275

[21] Celli, G.B., Denchi, E.L. and de Lange, T. (2006) Ku70 Stimulates Fusion of Dys- 
functional Telomeres yet Protects Chromosome Ends from Homologous Recombination. Nature Cell Biology, 8, 885-890. https://doi.org/10.1038/ncb1444

[22] Guo, X., Deng, Y., Lin, Y., Cosme-Blanco, W., Chan, S., He, H., Yuan, G., Brown, J.E. and Chang, S. (2007) Dysfunctional Telomeres Activate an ATM-ATR-Dependent DNA Damage Response to Suppress Tumorigenesis. The EMBO Journal, 26, 4709-4719. https://doi.org/10.1038/sj.emboj.7601893

[23] Denchi, E.L. and de Lange, T. (2007) Protection of Telomeres through Independent Control of ATM and ATR by TRF2 and POT1. Nature, 448, 1068-1071. https://doi.org/10.1038/nature06065

[24] Stansel, R.M., Subramanian, D. and Griffith, J.D. (2002) p53 Binds Telomeric Single Strand Overhangs and t-Loop Junctions in Vitro. Journal of Biological Chemistry, 277, 11625-11628. https://doi.org/10.1074/jbc.C100764200

[25] Bidzinska, J., Cimino-Reale, G., Zaffaroni, N. and Folini, M. (2013) G-Quadruplex Structures in the Human Genome as Novel Therapeutic Targets. Molecules, 18, 12368-12395. https://doi.org/10.3390/molecules181012368

[26] Williamson, J.R. (1994) G-Quartet Structures in Telomeric DNA. Annual Review of Biophysics and Biomolecular Structure, 23, 703-730.

https://doi.org/10.1146/annurev.bb.23.060194.003415

[27] Parkinson, G.N., Lee, M.P. and Neidle, S. (2002) Crystal Structure of Parallel Quadruplexes from Human Telomeric DNA. Nature, 417, 876-880. https://doi.org/10.1038/nature755

[28] Zahler, A.M., Williamson, J.R., Cech, T.R. and Prescott, D.M. (1991) Inhibition of Telomerase by G-Quartet DNA Structure. Nature, 350, 718-720. https://doi.org/10.1038/350718a0

[29] Lipps, H.J. and Rhodes, D. (2009) G-Quadruplex Structures: In Vivo Evidence and Function. Trends in Cell Biology, 19, 414-422. https://doi.org/10.1016/j.tcb.2009.05.002

[30] Rhodes, D. and Lipps, H.J. (2015) G-Quadruplexes and Their Regulatory Roles in Biology. Nucleic Acids Research, 43, 8627-8637. https://doi.org/10.1093/nar/gkv862

[31] Xu, Y. (2011) Chemistry in Human Telomere Biology: Structure, Function and Targeting of Telomere DNA/RNA. Chemical Society Reviews, 40, 2719-2740. https://doi.org/10.1039/c0cs00134a

[32] Kaushik, M., Kaushik, S., Bansal, A., Saxena, S. and Kukreti, S. (2011) Structural Diversity and Specific Recognition of Four Stranded G-Quadruplex DNA. Current Molecular Medicine, 11, 744-769. https://doi.org/10.2174/156652411798062421

[33] Burger, A.M., Dai, F., Schultes, C.M., Reszka, A.P., Moore, M.J., Double, J.A. and Neidle, S. (2005) The G-Quadruplex-Interactive Molecule BRACO-19 Inhibits Tumor Growth, Consistent with Telomere Targeting and Interference with Telomerase Function. Cancer Research, 65, 1489-1496. https://doi.org/10.1158/0008-5472.CAN-04-2910

[34] Phatak, P., Cookson, J.C., Dai, F., Smith, V., Gartenhaus, R.B., Stevens, M.F.G. and Burger, A.M. (2007) Telomere Uncapping by the G-Quadruplex Ligand RHPS4 Inhibits Clonogenic Tumour Cell Growth in Vitro and in Vivo Consistent with a Cancer Stem Cell Targeting Mechanism. British Journal of Cancer, 96, 1223-1233. https://doi.org/10.1038/sj.bjc.6603691

[35] Tauchi, T., Shin-Ya, K., Sashida, G., Sumi, M., Okabe, S., Ohyashiki, J.H. and Ohyashiki, K. (2006) Telomerase Inhibition with a Novel G-Quadruplex-Interactive Agent, Telomestatin: In Vitro and in Vivo Studies in Acute Leukemia. Oncogene, 25, 5719-5725. https://doi.org/10.1038/sj.onc.1209577 
[36] Cuenca, F., Greciano, O., Gunaratnam, M., Haider, S., Munnur, D., Nanjunda, R., Wilson, W.D. and Neidle, S. (2008) Tri- and Tetra-Substituted Naphthalene Diimides as Potent G-Quadruplex Ligands. Bioorganic \& Medicinal Chemistry Letters, 18, 1668-1673. https://doi.org/10.1016/j.bmcl.2008.01.050

[37] Feng, J., Funk, W.D., Wang, S.S. and Weinrich, S.L. (1995) The RNA Component of Human Telomerase. Science, 269, 1236-1241. https://doi.org/10.1126/science.7544491

[38] Martínez, P. and Blasco, M.A. (2015) Replicating through Telomeres: A Means to an End. Trends in Biochemical Sciences, 40, 504-515. https://doi.org/10.1016/j.tibs.2015.06.003

[39] Wyatt, H.D., West, S.C. and Beattie, T.L. (2010) In TERTpreting Telomerase Structure and Function. Nucleic Acids Research, 38, 5609-5622. https://doi.org/10.1093/nar/gkq370

[40] Ly, H. (2011) Telomere Dynamics in Induced Pluripotent Stem Cells: Potentials for Human Disease Modeling. World Journal of Stem Cells, 3, 89-95. https://doi.org/10.4252/wjsc.v3.i10.89

[41] Reste, J., Zvigule, G., Zvagule, T., Kurjane, N., Eglite, M., Gabruseva, N., Berzina, D., Plonis, J. and Miklasevics, E. (2014) Telomere Length in Chernobyl Accident Recovery Workers in the Late Period after the Disaster. Journal of Radiation Research, 55, 1089-1100. https://doi.org/10.1093/jrr/rru060

[42] Hug, N. and Lingner, J. (2006) Telomere Length Homeostasis. Chromosoma, 115, 413-425. https://doi.org/10.1007/s00412-006-0067-3

[43] Greider, C.W. and Blackburn, E.H. (1987) The Telomere Terminal Transferase of Tetrahymena Is a Ribonucleoprotein Enzyme with Two Kinds of Primer Specificity. Cell, 51, 887-898. https://doi.org/10.1016/0092-8674(87)90576-9

[44] Wright, W.E., Piatyszek, M.A., Rainey, W.E., Byrd, W. and Shay, J.W. (1996) Telomerase Activity in Human Germline and Embryonic Tissues and Cells. Developmental Genetics, 18, 173-179. https://doi.org/10.1002/(SICI)1520-6408(1996)18:2<173::AID-DVG10>3.0.CO;2-3

[45] Elwood, N. (2004) Telomere Biology of Human Hematopoietic Stem Cells. Cancer Control, 11, 77-85. https://doi.org/10.1177/107327480401100214

[46] Hodes, R.J., Hathcock, K.S. and Weng, N.P. (2002) Telomeres in T and B Cells. Nature Reviews Immunology, 2, 699-706. https://doi.org/10.1038/nri890

[47] Masutomi, K., Evan, Y.Y., Khurts, S., Ben-Porath, I., Currier, J.L., Metz, G.B., Brooks, M.W., Kaneko, S., Murakami, S., DeCaprio, J.A. and Weinberg, R.A. (2003) Telomerase Maintains Telomere Structure in Normal Human Cells. Cell, 114, 241-253. https://doi.org/10.1016/S0092-8674(03)00550-6

[48] Blackburn, E.H. (2000) Telomere States and Cell Fates. Nature, 408, 53-56. https://doi.org/10.1038/35040500

[49] Cheng, G., Kong, F., Luan, Y., Sun, C., Wang, J., Zhang, L., Jiang, B., Qi, T., Zhao, J., Zheng, C. and Xu, D. (2013) Differential Shortening Rate of Telomere Length in the Development of Human Fetus. Biochemical and Biophysical Research Communications, 442, 112-115. https://doi.org/10.1016/j.bbrc.2013.11.022

[50] Sanders, J.L. and Newman, A.B. (2013) Telomere Length in Epidemiology: A Biomarker of Aging, Age-Related Disease, Both, or Neither? Epidemiologic Reviews, 35, 112-131. https://doi.org/10.1093/epirev/mxs008

[51] Aubert, G. and Lansdorp, P.M. (2008) Telomeres and Aging. Physiological Reviews, 88, 557-579. https://doi.org/10.1152/physrev.00026.2007

[52] Comolli, L.R., Smirnov, I., Xu, L., Blackburn, E.H. and James, T.L. (2002) A Mole- 
cular Switch Underlies a Human Telomerase Disease. Proceedings of the National Academy of Sciences of the United States of America, 99, 16998-17003. https://doi.org/10.1073/pnas.262663599

[53] Shay, J.W. and Bacchetti, S. (1997) A Survey of Telomerase Activity in Human Cancer. European Journal of Cancer, 33, 787-791.

[54] Cao, Y., Bryan, T.M. and Reddel, R.R. (2008) Increased Copy Number of the TERT and TERC Telomerase Subunit Genes in Cancer Cells. Cancer Science, 99, 1092-1099. https://doi.org/10.1111/j.1349-7006.2008.00815.x

[55] Kim, N.W., Piatyszek, M.A., Prowse, K.R., Harley, C.B., et al. (1994) Specific Association of Human Telomerase Activity with Immortal Cells and Cancer. Science, 266, 2011-2015. https://doi.org/10.1126/science.7605428

[56] Vulliamy, T., Marrone, A., Goldman, F., Dearlove, A., Bessler, M., Mason, P.J. and Dokal, I. (2001) The RNA Component of Telomerase Is Mutated in Autosomal Dominant Dyskeratosis Congenita. Nature, 413, 432-435. https://doi.org/10.1038/35096585

[57] Garcia, C.K., Wright, W.E. and Shay, J.W. (2007) Human Diseases of Telomerase Dysfunction: Insights into Tissue Aging. Nucleic Acids Research, 35, 7406-7416. https://doi.org/10.1093/nar/gkm644

[58] Nakamura, T.M., Morin, G.B., Chapman, K.B., Weinrich, S.L., Andrews, W.H., Lingner, J., Harley, C.B. and Cech, T.R. (1997) Telomerase Catalytic Subunit Homologs from Fission Yeast and Human. Science, 277, 955-959.

https://doi.org/10.1126/science.277.5328.955

[59] Lingner, J. and Cech, T.R. (1996) Purification of Telomerase from Euplotes aediculatus: Requirement of a Primer 3' Overhang. Proceedings of the National Academy of Sciences of the United States of America, 93, 10712-10717.

[60] Jentsch, J.D., Redmond, D.E., Elsworth, J.D., Taylor, J.R., Youngren, K.D. and Roth, R.H. (1997) Enduring Cognitive Deficits and Cortical Dopamine Dysfunction in Monkeys after Long-Term Administration of Phencyclidine. Science, 277, 953-955. https://doi.org/10.1126/science.277.5328.953

[61] Sharma, G.G., Gupta, A., Wang, H., Scherthan, H., Dhar, S., Gandhi, V., Iliakis, G., Shay, J.W., Young, C.S. and Pandita, T.K. (2003) hTERT Associates with Human Telomeres and Enhances Genomic Stability and DNA Repair. Oncogene, 22, 131-146. https://doi.org/10.1038/sj.onc.1206063

[62] Smogorzewska, A. and de Lange, T. (2004) Regulation of Telomerase by Telomeric Proteins. Annual Review of Biochemistry, 73, 177-208. https://doi.org/10.1146/annurev.biochem.73.071403.160049

[63] Chang, J.T.-C., Chen, Y.-L., Yang, H.-T., Chen, C.-Y. and Cheng, A.-J. (2002) Differential Regulation of Telomerase Activity by Six Telomerase Subunits. The FEBS Journal, 269, 3442-3450. https://doi.org/10.1046/j.1432-1033.2002.03025.x

[64] Holt, S.E., Aisner, D.L., Baur, J., Tesmer, V.M., Dy, M., Ouellette, M., Trager, J.B., Morin, G.B., Toft, D.O., Shay, J.W., Wright, W.E. and White, M.A. (1999) Functional Requirement of p23 and Hsp90 in Telomerase Complexes. Genes \& Development, 13, 817-826. https://doi.org/10.1101/gad.13.7.817

[65] Liu, X., Bishop, J., Shan, Y., Pai, S., Liu, D., Murugan, A.K., Sun, H., El-Naggar, A.K. and Xing, M. (2013) Highly Prevalent TERT Promoter Mutations in Aggressive Thyroid Cancers. Endocrine-Related Cancer, 20, 603-610. https://doi.org/10.1530/ERC-13-0210

[66] Zhou, X., Zhu, H. and Lu, J. (2015) PTEN and hTERT Gene Expression and the Correlation with Human Hepatocellular Carcinoma. Pathology-Research and Practice, 211, 316-319. https://doi.org/10.1016/j.prp.2014.11.016 
[67] Kyo, S., Kanaya, T., Takakura, M., Tanaka, M. and Inoue, M. (1999) Human Telomerase Reverse Transcriptase as a Critical Determinant of Telomerase Activity in Normal and Malignant Endometrial Tissues. International Journal of Cancer, 80, 60-63.

https://doi.org/10.1002/(SICI)1097-0215(19990105)80:1<60::AID-IJC12>3.0.CO;2-E

[68] Poole, J.C., Andrews, L.G. and Tollefsbol, T.O. (2001) Activity, Function, and Gene Regulation of the Catalytic Subunit of Telomerase (hTERT). Gene, 269, 1-12. https://doi.org/10.1016/S0378-1119(01)00440-1

[69] Chiodi, I. and Mondello, C. (2012) Telomere-Independent Functions of Telomerase in Nuclei, Cytoplasm, and Mitochondria. Frontiers in Oncology, 2, 133. https://doi.org/10.3389/fonc.2012.00133

[70] Masutomi, K., Possemato, R., Wong, J.M., Currier, J.L., Tothova, Z., Manola, J.B., Ganesan, S., Lansdorp, P.M., Collins, K. and Hahn, W.C. (2005) The Telomerase Reverse Transcriptase Regulates Chromatin State and DNA Damage Responses. Proceedings of the National Academy of Sciences of the United States of America, 102, 8222-8227. https://doi.org/10.1073/pnas.0503095102

[71] Park, J.-I., Venteicher, A.S., Hong, J.Y., Choi, J., Jun, S., Shkreli, M., Chang, W., Meng, Z., Cheung, P., Ji, H., McLaughlin, M., et al. (2009) Telomerase Modulates Wnt Signalling by Association with Target Gene Chromatin. Nature, 460, 66-72. https://doi.org/10.1038/nature08137

[72] Maida, Y., Yasukawa, M., Furuuchi, M., Lassmann, T., Possemato, R., Okamoto, N., Kasim, V., Hayashizaki, Y., Hahn, W.C. and Masutomi, K. (2009) An RNA Dependent RNA Polymerase Formed by TERT and the RMRP RNA. Nature, 461, 230-235. https://doi.org/10.1038/nature08283

[73] Bellot, G.L. and Wang, X. (2013) Extra-Telomeric Effects of Telomerase (hTERT) in Cell Death. In: Rudner, J., Ed., Apoptosis, InTech.

[74] Ge, Z., Liu, C., Björkholm, M., Gruber, A. and Xu, D. (2006) Mitogen-Activated Protein Kinase Cascade-Mediated Histone H3 Phosphorylation Is Critical for Telomerase Reverse Transcriptase Expression/Telomerase Activation Induced by Proliferation. Molecular and Cellular Biology, 26, 230-237. https://doi.org/10.1128/MCB.26.1.230-237.2006

[75] Hanahan, D. and Weinberg, R.A. (2011) Hallmarks of Cancer: The Next Generation. Cell, 144, 646-674. https://doi.org/10.1016/j.cell.2011.02.013

[76] Klapper, W., Qian, W., Schulte, C. and Parwaresch, R. (2003) DNA Damage Transiently Increases TRF2 mRNA Expression and Telomerase Activity. Leukemia, 17, 2007-2015. https://doi.org/10.1038/sj.leu.2403086

[77] Ning, H., Li, T., Zhao, L., Li, T., Li, J., Liu, J., Liu, Z. and Fan, D. (2006) TRF2 Promotes Multidrug Resistance in Gastric Cancer Cells. Cancer Biology \& Therapy, 5, 950-956.

[78] Heselmeyer-Haddad, K., Sommerfeld, K., White, N.M., Chaudhri, N., Morrison, L.E., Palanisamy, N., Wang, Z.Y., Auer, G., Steinberg, W. and Ried, T. (2005) Genomic Amplification of the Human Telomerase Gene (TERC) in Pap Smears Predicts the Development of Cervical Cancer. The American Journal of Pathology, 166, 1229-1238. https://doi.org/10.1016/S0002-9440(10)62341-3

[79] Heselmeyer-Haddad, K., Janz, V., Castle, P.E., Chaudhri, N., White, N., Wilber, K., Morrison, L.E., Auer, G., Burroughs, F.H., Sherman, M.E. and Ried, T. (2003) Detection of Genomic Amplification of the Human Telomerase Gene (TERC) in Cytologic Specimens as a Genetic Test for the Diagnosis of Cervical Dysplasia. The American Journal of Pathology, 163, 1405-1416. https://doi.org/10.1016/S0002-9440(10)63498-0 
[80] Bryan, T.M., Englezou, A., Gupta, J., Bacchetti, S. and Reddel, R.R. (1995) Telomere Elongation in Immortal Human Cells without Detectable Telomerase Activity. The EMBO Journal, 14, 4240-4248.

[81] Henson, J.D., Neumann, A.A., Yeager, T.R. and Reddel, R.R. (2002) Alternative Lengthening of Telomeres in Mammalian Cells. Oncogene, 21, 598-610. https://doi.org/10.1038/sj.onc.1205058

[82] Liu, Y., Snow, B.E., Hande, M.P., Yeung, D., Erdmann, N.J., Wakeham, A., Itie, A., Siderovski, D.P., Lansdorp, P.M., Robinson, M.O. and Harrington, L. (2000) The Telomerase Reverse Transcriptase Is Limiting and Necessary for Telomerase Function in Vivo. Current Biology, 10, 1459-1462. https://doi.org/10.1016/S0960-9822(00)00805-8

[83] Lundblad, V. and Blackburn, E.H. (1993) An Alternative Pathway for Yeast Telomere Maintenance Rescues est ${ }^{-}$Senescence. Cell, 73, 347-360. https://doi.org/10.1016/0092-8674(93)90234-H

[84] Roth, C.W., Kobeski, F., Walter, M.F. and Biessmann, H. (1997) Chromosome End Elongation by Recombination in the Mosquito Anopheles gambiae. Molecular and Cellular Biology, 17, 5176-5183. https://doi.org/10.1128/MCB.17.9.5176

[85] Pardue, M.L., Rashkova, S., Casacuberta, E., DeBaryshe, P.G., George, J.A. and Traverse, K.L. (2005) Two Retrotransposons Maintain Telomeres in Drosophila. Chromosome Research, 13, 443-453. https://doi.org/10.1007/s10577-005-0993-6

[86] Cesare, A.J. and Griffith, J.D. (2004) Telomeric DNA in ALT Cells Is Characterized by Free Telomeric Circles and Heterogeneous t-Loops. Molecular and Cellular Biology, 24, 9948-9957. https://doi.org/10.1128/MCB.24.22.9948-9957.2004

[87] Artandi, S.E. and DePinho, R.A. (2000) A Critical Role for Telomeres in Suppressing and Facilitating Carcinogenesis. Current Opinion in Genetics \& Development, 10, 39-46. https://doi.org/10.1016/S0959-437X(99)00047-7

[88] Rudolph, K.L., Millard, M., Bosenberg, M.W. and DePinho, R.A. (2001) Telomere Dysfunction and Evolution of Intestinal Carcinoma in Mice and Humans. Nature Genetics, 28, 155-159. https://doi.org/10.1038/88871

[89] Zhang, P.-H., Zou, L. and Tu, Z.-G. (2006) RNAi-hTERT Inhibition Hepatocellular Carcinoma Cell Proliferation via Decreasing Telomerase Activity. Journal of Surgical Research, 131, 143-149. https://doi.org/10.1016/j.jss.2005.09.017

[90] Campanella, N.C., Celestino, R., Pestana, A., Scapulatempo-Neto, C., De Oliveira, A.T., Brito, M.J., Gouveia, A., Lopes, J.M., Guimarães, D.P., Soares, P. and Reis, R.M. (2015) Low Frequency of TERT Promoter Mutations in Gastrointestinal Stromal Tumors (GISTs). European Journal of Human Genetics, 23, 877-879. https://doi.org/10.1038/ejhg.2014.195

[91] Huang, D.S., Wang, Z., He, X.J., Diplas, B.H., Yang, R., Killela, P.J., Meng, Q., Ye, Z.Y., Wang, W., Jiang, X.T., Xu, L., et al. (2015) Recurrent TERT Promoter Mutations Identified in a Large-Scale Study of Multiple Tumour Types Are Associated with Increased TERT Expression and Telomerase Activation. European Journal of Cancer, 51, 969-976. https://doi.org/10.1016/j.ejca.2015.03.010

[92] Killela, P.J., Reitman, Z.J., Jiao, Y., Bettegowda, C., Agrawal, N., Diaz, L.A., Friedman, A.H., Friedman, H., Gallia, G.L., Giovanella, B.C., Grollman, A.P., et al. (2013) TERT Promoter Mutations Occur Frequently in Gliomas and a Subset of Tumors Derived from Cells with Low Rates of Self-Renewal. Proceedings of the National Academy of Sciences of the United States of America, 110, 6021-6026. https://doi.org/10.1073/pnas.1303607110

[93] Huang, F.W., Hodis, E., Xu, M.J., Kryukov, G.V., Chin, L. and Garraway, L.A. (2013) Highly Recurrent TERT Promoter Mutations in Human Melanoma. Science, 
339, 957-959. https://doi.org/10.1126/science.1229259

[94] Simon, M., Hosen, I., Gousias, K., Rachakonda, S., Heidenreich, B., Gessi, M., Schramm, J., Hemminki, K., Waha, A. and Kumar, R. (2014) TERT Promoter Mutations: A Novel Independent Prognostic Factor in Primary Glioblastomas. Neuro-Oncology, 17, 45-52. https://doi.org/10.1093/neuonc/nou158

[95] Horn, S., Figl, A., Rachakonda, P.S., Fischer, C., Sucker, A., Gast, A., Kadel, S., Moll, I., Nagore, E., Hemminki, K., Schadendorf, D. and Kumar, R. (2013) TERT Promoter Mutations in Familial and Sporadic Melanoma. Science, 339, 959-961. https://doi.org/10.1126/science.1230062

[96] Chen, Y.-L., Jeng, Y.-M., Chang, C.-N., Lee, H.-J., Hsu, H.-C., Lai, P.-L. and Yuan, R.-H. (2014) TERT Promoter Mutation in Resectable Hepatocellular Carcinomas: A Strong Association with Hepatitis C Infection and Absence of Hepatitis B Infection. International Journal of Surgery, 12, 659-665.

https://doi.org/10.1016/j.ijsu.2014.05.066

[97] Rachakonda, P.S., Hosen, I., de Verdier, P.J., Fallah, M., Heidenreich, B., Ryk, C., Wiklund, N.P., Steineck, G., Schadendorf, D., Hemminki, K. and Kumar, R. (2013) TERT Promoter Mutations in Bladder Cancer Affect Patient Survival and Disease Recurrence through Modification by a Common Polymorphism. Proceedings of the National Academy of Sciences of the United States of America, 110, 17426-17431. https://doi.org/10.1073/pnas.1310522110

[98] Griewank, K.G., Murali, R., Puig-Butille, J.A., Schilling, B., Livingstone, E., Potrony, M., Carrera, C., Schimming, T., Möller, I., Schwamborn, M., Sucker, A., et al. (2014) TERT Promoter Mutation Status as an Independent Prognostic Factor in Cutaneous Melanoma. Journal of the National Cancer Institute, 106, 1-13. https://doi.org/10.1093/jnci/dju246

[99] Xing, M., Liu, R., Liu, X., Murugan, A.K., Zhu, G., Zeiger, M.A., Pai, S. and Bishop, J. (2014) BRAF V600E and TERT Promoter Mutations Cooperatively Identify the Most Aggressive Papillary Thyroid Cancer with Highest Recurrence. Journal of Clinical Oncology, 32, 2718-2726. https://doi.org/10.1200/JCO.2014.55.5094

[100] Ma, X., Gong, R., Wang, R., Pan, Y., Cai, D., Pan, B., Li, Y., Xiang, J., Li, H., Zhang, J., Sun, Y. and Chen, H. (2014) Recurrent TERT Promoter Mutations in Non-Small Cell Lung Cancers. Lung Cancer, 86, 369-373. https://doi.org/10.1016/j.lungcan.2014.10.009

[101] Hosen, I., Rachakonda, P.S., Heidenreich, B., Sitaram, R.T., Ljungberg, B., Roos, G., Hemminki, K. and Kumar, R. (2015) TERT Promoter Mutations in Clear Cell Renal Cell Carcinoma. International Journal of Cancer, 136, 2448-2452.

https://doi.org/10.1002/ijc.29279

[102] Biron-Shental, T., Kitay-Cohen, Y., Tene, T., Sharony, R. and Amiel, A. (2012) Increased TERC Gene Copy Number in Amniocytes from Fetuses with Trisomy 18 or a Sex Chromosome Aneuploidy. Gene, 506, 46-49. https://doi.org/10.1016/j.gene.2012.06.072

[103] Liu, L., Bailey, S.M., Okuka, M., Muñoz, P., Li, C., Zhou, L., Wu, C., Czerwiec, E., Sandler, L., Seyfang, A., Blasco, M.A. and Keefe, D.L. (2007) Telomere Lengthening Early in Development. Nature Cell Biology, 9, 1436-1441.

https://doi.org/10.1038/ncb1664

[104] Ruden, M. and Puri, N. (2013) Novel Anticancer Therapeutics Targeting Telomerase. Cancer Treatment Reviews, 39, 444-456.

https://doi.org/10.1016/j.ctrv.2012.06.007 